\title{
Asymmetric effects of exchange rate changes on the demand for divisia money in Malaysia
}

\author{
Choi-Meng Leong \\ Faculty of Business and Information Science, UCSI University \\ Malaysia \\ mandyleongcm@gmail.com
}

\section{Chin-Hong Puah}

Faculty of Economics and Business, Universiti Malaysia Sarawak.

Malaysia

chpuah@unimas.my

\section{Evan Lau}

Faculty of Economics and Business, Universiti Malaysia Sarawak

Malaysia

Iphevan@unimas.my

\author{
Abu Mansor Shazali \\ Faculty of Economics and Business, Universiti Malaysia Sarawak \\ Malaysia \\ mshazali@unimas.my
}

Abstract. Financial liberalisation has advanced the transformation of the financial market as more interest-bearing financial derivatives are introduced. Performance of the equal-weighted monetary aggregates has been affected and therefore disrupted the stability of money demand. Effectiveness of monetary policy is a concern as stability of money demand is required for a stable velocity derivation. 
exchange rate and money demand. A stable money demand function contributes to formulation of monetary policy in Malaysia.

Keywords: financial liberalization, divisia monetary aggregate, exchange rate, asymmetric, money demand.

JEL Classification: C41, E52

\section{INTRODUCTION}

Financial liberalisation has led to financial-sector transformation in emerging economies such as Malaysia, which is also a leading global Islamic finance hub. Malaysia underwent financial liberalisation as early as 1978 with liberalisation in deposit and lending rates. A remarkable change was seen between 1988 and 1993 when the money market-London interbank offered rate (LIBOR) differential rose and boosted foreign capital inflows (Dekle \& Pradhan, 1997). The key evolution in the financial sector from 1997 to 2010 involved the financial sector diversification that was achieved by a deep and liquid debt securities market, consolidation and rationalisation in the banking industry and better market orientation (Bank Negara Malaysia, 2011). Cost-effective hedging was used to promote deep and liquid interest rate derivatives in financial institutions and corporations (Bank Negara Malaysia, 2011). The framework for the Financial Sector Blueprint (2011-2020) further enhanced financial liberalisation, including the introduction of innovative channels such as agent banking, mobile banking and some other innovative products and services like flexible micro-financing, micro-savings products and micro-insurance or takaful, among others. With this significant financial development in Malaysia, government policies are important to ensure continuous economic growth.

Along with passive fiscal policy, active monetary policy is critical for domestic equilibrium determination (Tsuzuki, 2016). Money neutrality is one of the important issues for monetary policy (Wlodarczyk, 2014). In addition, the choice of target for monetary policy as well as the variables used to monitor the monetary conditions can be affected by financial liberalisation as the central bank normally employs quantity variables, such as broad money, as targets (Dekle \& Pradhan, 1997). Stability of monetary aggregates has been affected due to financial liberalisation. As a result, money demand has become unstable. Under monetary targeting, a stable money demand function is critical for predicting future inflation and output, in which supply of liquidity must correspond to the demand for money to prevent excess money supply that will prompt inflation. Consequently, Malaysia shifted from monetary targeting to interest targeting in November 1995. The focus of policies changed to short-term interest rates while monetary authority monitors money and credit growth in the decision-making process (Dekle \& Pradhan, 1997). The ability to estimate the money demand function is still the key concern of policymakers as the combination of money demand and money supply is used to determine interest rates, which can affect the ultimate goal of monetary policy (Kamaruddin \& Khalid, 2016).

Instability of the conventional monetary aggregate can be due to the approach used for its construction. With rapid liberalisation in interest rates in Malaysia, the ability of conventional monetary aggregate to incorporate the change is unknown. The conventional money supply is derived by simple summation of all monetary components to form money, in which all monetary aggregates are perfectly substituted. Therefore, monetary assets have identical opportunity costs and are assigned equal weights (Drake \& Fleissig, 2004). As various monetary assets possess different opportunity costs, lack of microeconomic foundation supports the perfect substitution assumption. If additional monetary assets are included in the construction of money, the perfect substitution assumption of monetary assets is inappropriate (Thornton \& Yue, 1992). Thus, 
monetary assets with different opportunity costs must be assigned different weights. Barnett (1980) introduced the concept of using different weights for various monetary assets with dissimilar returns in computing the monetary aggregate. The monetary aggregate constructed under this approach is called the Divisia monetary aggregate. The weightage is calculated based on the monetary services provided by monetary assets. As a result, the effect of change in opportunity costs among various monetary assets can be captured by the Divisia monetary aggregate. The computation approach is more consistent with the development of financial liberalisation, in which many new monetary assets are launched with various rates of return. For instance, Divisia monetary aggregate was found significant in explaining the exchange rate (Leong et al., 2018a; Leong et al., 2018b). With the innovation in monetary aggregate computation, this provides an alternative way to estimate the money demand function for Malaysia. Malaysia had undergone financial crises as well as implemented different exchange rate regimes but subsisted in the era of globalisation and export rivalry (Chan et al., 2019).

In addition, financial liberalisation also contributes to a more integrated financial market in Malaysia that may alter the money demand determinants. In Malaysia, the market share of global players in the banking sector is as high as an estimated $20 \%$ while the insurance and takaful sectors have an estimated two-thirds, which has promoted international trade and investment flows, new areas of economic development, employment and financial system diversification and development (Bank Negara Malaysia, 2011). Non-resident portfolio plays a role in foreign exchange market (Ministry of Finance Malaysia, 2018). Thus, fluctuations in the exchange rate affect policymakers, multinational firms, international traders and international investors. For instance, volatility of exchange rate was found affecting the real exports of Malaysia (Wong \& Lee, 2016). Mundell (1963) was the pioneer in theoretically relating the exchange rate to money demand in addition to income and interest rate. Since then, exchange rate has been tested empirically to prove this hypothesis. The empirical studies relate exchange rate to money demand via the wealth effect and substitution effect. The wealth effect exists if depreciation in domestic currency or appreciation in foreign currency increases the value of foreign assets expressed in domestic currency, which are held by local residents and thus increase the demand for money (Arango \& Nadiri, 1981). The substitution effect presumes that further appreciation (depreciation) in foreign (domestic) currency is expected when foreign (domestic) currency appreciates (depreciates) and, therefore, domestic residents demand more (less) for foreign (domestic) currency instead of local currency (Bahmani-Oskooee \& Pourheydarian 1990; Haider et al., 2017). Succinctly, exchange rate is one of the key determinants of cash demand in the long run (Khatat, 2018).

The responses of the market players to changes in the exchange rate may not be identical. Most studies assume that the determinants of money demand have symmetric effects on the demand for money. McNown and Walace (1992), Civcir (2003) and Bahmani-Oskooee et al. (2013) found that the exchange rate has a symmetric effect on money demand. For Malaysia, Azali et al. (2000) and Leong et al. (2010) also estimated the money demand function by including the exchange rate as one of the determinants in a symmetric setting. However, Bahmani-Oskooee and Bahmani (2015) found that exchange rate changes had asymmetric effects on the demand for money in Iran. In a recent study, asymmetric effects of exchange rate changes were also found by Bahmani-Oskooee and Baek (2017) in Korea. In fact, asymmetric effects capture the unequal upswing and downswing changes in the exchange rate. Failure to consider this effect will result in invalid information regarding the cointegration between the variables.

Accordingly, the motivation of this study is to derive a stable money demand function for Malaysia. First, how stable is the money demand function using the Divisia monetary aggregate as the money supply? Second, are exchange rate changes the determinants of money demand and do they have asymmetric effects on money demand? 


\section{MODEL AND METHODOLOGY}

The standard money demand function is specified following Goldfeld (1973) by including a scale variable and the opportunity cost of holding money. For the case of Malaysia, the exchange rate variable is included in the standard money demand model (Azali et al., 2000):

$$
M D_{t}=\beta_{0}+\beta_{1} y_{t}+\beta_{2} r_{t}+\beta_{3} e r_{t}+e_{t}
$$

where $M D_{t}$ is the real money demand, $y_{t}$ designates the real income, $r_{t}$ is the interest rate and $e r_{t}$ denotes the exchange rate.

The nonlinear autoregressive distributed lag (NARDL) model proposed by Shin et al. (2011) is used to estimate the asymmetric effect of the exchange rate in the long run and short run within the vector autoregressive (VAR) framework. The long-run equation to account for the asymmetric effect is expressed as (Shin et al., 2011):

$$
M D_{t}=\alpha_{0}+\alpha_{1} y_{t}+\alpha_{2} r_{t}+\alpha_{3} e r_{t}^{+}+\alpha_{4} e r_{t}^{-}+e_{t}
$$

where $M D_{t}$ is the real Divisia money demand while $y_{t}, r_{t}$ and $e r_{t}$ are the real income, interest rate and nominal exchange rate, respectively. The cointegrating vector is $=\left(\alpha_{0}, \alpha_{1}, \alpha_{2}, \alpha_{3}, \alpha_{4}\right)$, which comprises the longrun parameters for estimation, and $e r_{t}^{+}$and $e r_{t}^{-}$are the partial sums of positive and negative changes for the nominal exchange rate, which are derived from the following equations:

$$
e r_{t}^{+}=\sum_{i=1}^{t} \Delta e r_{i}^{+}=\sum_{i=1}^{t} \max \left(\Delta e r_{i}, 0\right)
$$

and

$$
e r_{t}^{-}=\sum_{i=1}^{t} \Delta e r_{i}^{-}=\sum_{i=1}^{t} \min \left(\Delta e r_{i}, 0\right)
$$

where $e r_{t}^{+}$represents the increase in $e r_{t}$ while $e r_{t}^{-}$indicates the decrease in $e r_{t}$. The coefficient of $\alpha$ is used to identify the long-run relationship between $\mathrm{er}_{t}^{+}$(or $\mathrm{er}_{t}^{-}$) and money demand. For instance, a 1\% appreciation in the currency increases the money demand by $2 \%$, but a $1 \%$ depreciation may not reduce the money demand by $2 \%$ based on expectations (Bahmani-Oskooee \& Baek, 2017). A wealth effect exists if an appreciation (depreciation) in foreign currency leads to an increase (decrease) in the demand for domestic currency. Conversely, an appreciation (depreciation) in foreign currency leads to a decrease (increase) in the demand for domestic currency, which denotes the presence of the substitution effect. To summarise the wealth or substitution effect of nominal exchange rates, the expected signs of the coefficients for both $e r_{t}^{+}$and $e r_{t}^{-}$are presented in Table 1 .

Table 1

Expected signs of coefficients

\begin{tabular}{|l|c|c|}
\hline & $\boldsymbol{e r}_{t}^{+}$ & $\boldsymbol{e r}_{\boldsymbol{t}}^{-}$ \\
\hline Wealth effect & + & - \\
\hline Substitution effect & - & + \\
\hline
\end{tabular}


Equation (2) is then transformed to the autoregressive distributed lag (ARDL) framework of Pesaran and Shin (1999) and Pesaran et al. (2001), expressed as:

$$
\begin{aligned}
\Delta M D_{t}=\alpha+ & \sum_{i=1}^{p} \gamma_{1 i} \Delta M D_{t-i}+\sum_{i=0}^{q_{1}} \gamma_{3 i} \Delta y_{t-i}+\sum_{i=0}^{q_{2}} \gamma_{4 i} \Delta r_{t-i}+\sum_{i=0}^{q_{3}}\left(\gamma_{2 i}^{+} \Delta e r_{t-i}^{+}+\gamma_{2 i}^{-} \Delta e r_{t-i}^{-}\right)+ \\
& +\theta_{0} M D_{t-1}+\theta_{1} y_{t-1}+\theta_{2} r_{t-1}+\theta_{3} e r_{i-1}^{+}+\theta_{4} e r_{i-1}^{-}+\mu_{t}
\end{aligned}
$$

where the coefficients of $\gamma$ and $\theta$ are used to capture the short-run and long-run effects, respectively. On the other hand, $p, q_{1}, q_{2}$ and $q_{3}$ are the lag orders. The long-run elasticities of the exchange rates increase and decrease on money demand is calculated by dividing the coefficients of $\operatorname{der}(\theta)$ by $\theta_{0}$. The short-run effect of a er increase on money demand is measured by $\sum_{i=0}^{q_{j}} \gamma_{i}^{+}$while $\sum_{i=0}^{q_{j}} \gamma_{i}^{-}$is used to compute the short-run effect of a $e r$ decrease on money demand, where $j=1,2$ or 3 .

The standard ordinary least squares (OLS) method is used to estimate Equation (5). The insignificant lags are eliminated by utilising the general-to-specific procedure to derive the ultimate specification of the NARDL money demand model (Katrakilidis \& Trachanas, 2012). Next, the presence of cointegration among the variables is tested using the Wald F test. The null hypothesis of no cointegration among the variables is stated as follows:

$$
H_{0}: \theta_{0}=\theta_{1}=\theta_{2}=\theta_{3}=\theta_{4}=0
$$

which is tested against the alternate hypothesis of the existence of cointegration among the variables. The alternate hypothesis is:

$$
H_{1}: \theta_{0} \neq \theta_{1} \neq \theta_{2} \neq \theta_{3} \neq \theta_{4} \neq 0 \text {. }
$$

The inferences on long- and short-run asymmetries can only be drawn if cointegration exists among the variables.

Quarterly data ranging from 1991:Q1 to 2018:Q4 are used for estimation of the money demand function. The year 1991 also marked the year for the launch of the National Development Policy. Real money demand is measured by using the Divisia M2 monetary aggregate. The interest rate for Divisia money is proxied by the dual price, which is formulated as a chained superlative index identical to the Divisia monetary aggregate. The real gross domestic product (GDP) and nominal exchange rate are used as proxies for the real income and exchange rate. All data are transformed to natural logarithm, except for dual price. The variables used are summarised in Table 2. 
Summary of variables under investigation

\begin{tabular}{|l|l|l|}
\hline Notation & Variable & Description \\
\hline RDM2 & $\begin{array}{l}\text { Real Divisia money } \\
\text { demand }\end{array}$ & Divisia M2 monetary aggregate \\
\hline RGDP & Real income & Real gross domestic product (GDP) \\
\hline DPM2 & Nominal interest rate & Dual price \\
\hline ER & Nominal exchange rate & Ringgit per United States (U.S.) dollar \\
\hline ERPOS & $\begin{array}{l}\text { Partial sums of positive } \\
\text { exchange rate changes }\end{array}$ & $\begin{array}{l}\text { Derived from nominal exchange rate using NARDL } \\
\text { approach }\end{array}$ \\
\hline ERNEG & $\begin{array}{l}\text { Partial sums of negative } \\
\text { exchange rate changes }\end{array}$ & $\begin{array}{l}\text { Derived from nominal exchange rate using NARDL } \\
\text { approach }\end{array}$ \\
\hline
\end{tabular}

Note: The natural logarithm term for RDM2, RGDP, ERPOS and ERNEG is denoted as LRDM2, LRGDP, LERPOS and LERNEG, respectively.

\section{RESULTS AND DISCUSSION}

Although the unit root test is not a compulsory test for the bounds testing approach, a unit root test is conducted to ensure that there is no I(2) variable. The results of the unit root test are tabulated in Table 3. By utilising the augmented Dickey-Fuller (ADF) unit root test, all variables are integrated on the order of one. The Kwiatkowski-Phillips-Schmidt-Shin (KPSS) stationary test is conducted to reconfirm the results of the ADF test. The results of the KPSS test are consistent with the ADF test results as all variables are stationary in first difference. As there is no $\mathrm{I}(2)$ variable, the bounds testing approach is valid for the estimation of long-run and short-run relationships among the variables.

Table 3

Unit root test results

\begin{tabular}{|l|c|c|c|c|}
\hline & \multicolumn{2}{|c|}{ ADF } & \multicolumn{2}{c|}{ KPSS } \\
\hline Variable & Level & First Difference & Level & First Difference \\
\hline LRDM2 & $-1.6184(1)$ & $-8.1998(0)^{* * *}$ & $0.1249(7)^{*}$ & $0.0963(7)$ \\
\hline LRGDP & $-1.4354(9)$ & $-4.7107(8)^{* * *}$ & $0.1763(8)^{* *}$ & $0.1513(8)$ \\
\hline DPM2 & $-2.2733(0)$ & $-9.2197(0)^{* * *}$ & $0.2045(8)^{* *}$ & $0.0526(3)$ \\
\hline LERPOS & $-1.7050(1)$ & $-7.6581(0)^{* * *}$ & $0.1268(9)^{*}$ & $0.0947(5)$ \\
\hline LERNEG & $-1.0209(0)$ & $-9.7281(0)^{* * *}$ & $0.2097(8)^{* *}$ & $0.1902(1)$ \\
\hline
\end{tabular}

Notes: The constant and trend terms are included in the estimation of ADF and KPSS tests. Schwarz information criterion is used for the lag selection in ADF test. 
Nonlinear ARDL estimation results

\begin{tabular}{|c|c|c|}
\hline \multicolumn{3}{|c|}{ Panel A Estimated Model } \\
\hline Independent Variable & Coefficient & p-value \\
\hline Constant & -0.1352 & 0.1947 \\
\hline LRDM2(-1) & -0.1800 & 0.0001 \\
\hline LRGDP(-1) & 0.2201 & 0.0000 \\
\hline DPM2(-1) & -0.0063 & 0.0783 \\
\hline LERPOS(-1) & -0.0729 & 0.0049 \\
\hline LERNEG(-1) & -0.0558 & 0.2026 \\
\hline$\Delta \mathrm{LRDM} 2(-1)$ & 0.0998 & 0.2599 \\
\hline$\Delta \mathrm{LRDM} 2(-2)$ & 0.3556 & 0.0007 \\
\hline$\Delta \operatorname{LRDM} 2(-3)$ & 0.1366 & 0.1769 \\
\hline$\Delta \mathrm{LRGDP}$ & -0.1834 & 0.0158 \\
\hline$\Delta \mathrm{LRGDP}(-2)$ & -0.1136 & 0.0794 \\
\hline$\Delta \mathrm{LRGDP}(-3)$ & -0.1648 & 0.0082 \\
\hline$\Delta \operatorname{LRGDP}(-7)$ & -0.1222 & 0.0430 \\
\hline$\triangle \mathrm{DPM} 2(-1)$ & -0.0079 & 0.2040 \\
\hline$\triangle \mathrm{DPM} 2(-2)$ & 0.0199 & 0.0025 \\
\hline$\Delta \mathrm{DPM} 2(-3)$ & 0.0030 & 0.6081 \\
\hline$\Delta$ LERPOS $(-2)$ & -0.4019 & 0.0000 \\
\hline$\triangle \mathrm{LERPOS}(-4)$ & 0.1837 & 0.0162 \\
\hline$\triangle \mathrm{LERPOS}(-5)$ & 0.1791 & 0.0112 \\
\hline$\triangle \mathrm{LERNEG}$ & -0.1999 & 0.1042 \\
\hline$\Delta$ LERNEG(-2) & 0.1965 & 0.0990 \\
\hline$\Delta$ LERNEG(-3) & 0.1156 & 0.3315 \\
\hline$\Delta$ LERNEG(-5) & -0.3491 & 0.0039 \\
\hline \multicolumn{3}{|c|}{ Panel B Diagnostic Statistics } \\
\hline R-squared & 0.6288 & \\
\hline Serial Correlation & 0.2961 & 0.7446 \\
\hline Functional Form & 1.6534 & 0.1022 \\
\hline Normality & 2.0864 & 0.3523 \\
\hline Heteroskedasticity & 0.0959 & 0.7575 \\
\hline CUSUM & Stable & \\
\hline CUSUM of Squares & Stable & \\
\hline
\end{tabular}

Notes: Serial correlation refers to the Lagrange multiplier (LM) test of residual serial correlation. Ramsey's RESET test employs the square of fitted values to check the functional form. The Jarque-Bera normality test is founded on the skewness and kurtosis of residuals tests. The heteroskesdascity (ARCH) test is used to regress squared residuals on squared fitted values. The stability test comprises cumulative sum of recursive residuals test (CUSUM) and cumulative sum of squares of recursive residual test (CUSUM of squares). 
To carry out NARDL, a maximum of eight lags is levied on the estimated model (Bahmani-Oskooee and Baek 2017; Bahmani-Oskooee and Nayeri 2017). The model estimation results are presented in Table 4. The model is checked by performing a set of diagnostic tests. The Lagrange multiplier test is used to identify serial correlation while Ramsey's RESET test is used to detect model misspecification. Both statistics are insignificant, indicating that the model is well specified and free from residual autocorrelation. A normality test is performed to scrutinise the skewness and kurtosis of residuals and the insignificant statistic verifies that the residuals are normally distributed. CUSUM and CUSUM of squares tests also offer evidence of the stability of the model tested. The results indicate that a stable money demand model can be derived by using the Divisia monetary aggregate as well as by including exchange rate changes as determinants of money demand. From Table 4, the short-run analysis indicates that LRDM2, LRGDP, DPM2, LERPOS and LERNEG transmit at least one significant lagged estimate and thus imply that all variables have short-run effects on money demand. To check whether the short-run asymmetric effects are translated to the long run, a bounds test for nonlinear cointegration is performed (see Table 5).

Table 5

Bounds test for nonlinear cointegration

\begin{tabular}{|c|c|c|c|c|}
\hline $\begin{array}{l}\text { Money Demand } \\
\text { Specification }\end{array}$ & F-Statistics & $\begin{array}{c}95 \% \text { Lower } \\
\text { Bound }\end{array}$ & $\begin{array}{c}95 \% \text { Upper } \\
\text { Bound }\end{array}$ & Conclusion \\
\hline RDM2 Model & 5.0220 & 2.86 & 4.01 & Cointegration \\
\hline
\end{tabular}

Based on Table 5, the estimated F-statistic is 5.0220, which is greater than the critical upper bound value and thus supports the presence of cointegration. The finding enables the exploration of the long-run relations among real GDP, dual price, the nominal exchange rate and real money demand as well as changes in the nominal exchange rate on real money demand.

The results for the long-run relation are presented in Table 6. The long-run coefficient for real GDP is positive and significant at the $1 \%$ significance level. The value of income elasticity is greater than one, which indicates certain economies of scale (Bahmani-Oskooee and Baek, 2017). For dual price, the coefficient value is negative and significant at the $10 \%$ level of significance. The finding is in line with a priori theory of money demand. The results in Table 6 also show that the long-run effect of the exchange rate is asymmetric.

Table 6

Long-run relation

\begin{tabular}{|l|c|c|}
\hline Variables & Coefficient & p-value \\
\hline Constant & -0.7511 & 0.6131 \\
\hline LRGDP & 1.2227 & 0.0000 \\
\hline DPM2 & -0.0348 & 0.0874 \\
\hline LERPOS & -0.4049 & 0.0001 \\
\hline LERNEG & -0.3100 & 0.1306 \\
\hline
\end{tabular}

A significant negative coefficient value is found for LNERPOS, while an insignificant coefficient value is found for LNERNEG. The partial adjustment for the presence of asymmetric effects is supported by Bahmani-Oskooee and Baek (2016) as well as Bahmani-Oskooee and Baek (2017). The significant negative coefficient of LNERPOS indicates that when the U.S. dollar appreciates, Malaysia holds less in ringgits. 
Thus, a significant long-run effect exists for U.S. dollar appreciation on the demand for money in Malaysia, supporting the substitution effect. When the U.S. dollar appreciates, Malaysia will expect the U.S. dollar to further appreciate and thus buy and hold less in ringgits. The result is consistent with Marashdeh (1998) and Azali et al. (2000). The substitution effect is stronger in Malaysia as the central bank can manage the floating exchange rate to reduce the pressure on the ringgit and, therefore, change the public expectation. In addition, due to the financial liberalisation, the convertibility of the exchange rate can be enhanced and more buying and selling of currencies can be boosted through exchange rate derivatives. Therefore, by separating appreciation from depreciation, appreciation has long-run effects on the money demand.

\section{CONCLUSION}

The performance of conventional monetary aggregates in Malaysia has been affected by financial liberalisation. To consider this impact of financial liberalisation, the Divisia monetary aggregate is utilised to estimate the money demand function. The results of this study specify that a stable money demand function can be derived by using the Divisia monetary aggregate, which means that financial liberalisation has an impact on the monetary aggregate used for estimating the money demand function. This also provides an alternative for policymakers for a more stable money demand function for interest rate determination under interest targeting. Furthermore, the effectiveness of monetary policy also depends on the stability of the velocity of money, which is facilitated by a stable money demand (Bahmani-Oskooee \& Baek, 2016). Hence, identifying the missing variable to define the demand for money is critical. In this study, the exchange rate is included as one of the determinants of money demand. When currency depreciation is separated from currency appreciation, the findings indicate that the exchange rate has asymmetric effects on money demand via foreign currency appreciation. Positive partial sum of exchange rate is found significant with negative coefficient. When foreign currency appreciates, Malaysians expect further appreciation of foreign currecncy. Consequently, Malaysians hold more dollars while hold less local currency. This implies the presence of substitution effect, in which Malaysians will buy or sell dollars for speculation purpose. The other determinant, income, is also highly significant and possesses expected positive coefficient value. Finally, the dual price, which shows expected negative sign of coefficient is also significant in explaining the money demand. In short, the impact of exchange rate appreciation in addition to income and interest rate should be considered in the money demand determination for policy formulation purposes.

\section{ACKNOWLEDGEMENT}

Financial support from University of Malaysia Sarawak (UNIMAS) via Dana Principal Investigator research grant: 03(DPI21)985/2013(04) is gratefully acknowledged.

\section{REFERENCES}

Arango, S., \& Nadiri, M.I. (1981). Demand for Money in Open Economies. Journal of Monetary Economics, 7, 69-83.

Azali, M., Baharumshah, A.Z., \& Habibullah, M.S. (2000). Exchange Rate and the Demand for Money in Malaysia. Pertanika Journal of Social Sciences \& Humanities, 8(2), 71-75.

Bahmani-Oskooee, M., \& Baek, J. (2016). Global Financial Crisis of 2008, Asymmetric Effects of Exchange Rate Changes, and Stability of the Demand for Money in Japan. Journal of Reviews on Global Economics, 5, 273-280.

Bahmani-Oskooee, M., \& Baek, J. (2017). Do Exchange Rate Changes Have Symmetric or Asymmetric Effects on the Demand for Money in Korea? Review of Economic Analysis, 9, 155-168.

Bahmani-Oskooee, M., \& Bahmani, S. (2015). Nonlinear ARDL Approach and the Demand for Money in Iran. Economics Bulletin, 35, 381-391. 
Bahmani-Oskooee, M., Kutan, A. M., \& Xi, D. (2013). The Impact of Economic and Monetary Uncertainty on the Demand for Money in Emerging Economies. Applied Economics, 45, 3278-3287.

Bahmani-Oskooee, M., \& Nayeri, M.M. (2017). Policy Uncertainty and the Demand for Money in Australia: An Asymmetry Analysis. Munich Personal RePEc Archive (MPRA) paper No. 82846.

Bahmani-Oskooee, M., \& Pourheydarian, M. (1990). Exchange Rate Sensitivity of the Demand for Money and Effectiveness of Fiscal and Monetary Policies. Applied Economics, 22, 1377-1384.

Bank Negara Malaysia (2011). Financial Sector Blueprint 2011-2020. Kuala Lumpur: Bank Negara Malysia.

Barnett, W.A. (1980). Economic Monetary Aggregates: An Application of Index Number and Aggregation Theory. Journal of Econometrics, 14, 11-48.

Chan, T.H., Puah, C.H., \& Wong, S.S.L. (2019). Exchange Rates, Monetary Aggregates, Industrial Production and Shock Adjustments in Malaysia after the Capital Control. International Journal of Business and Society, 20(1), 95110.

Civcir, I. (2003). Money Demand, Financial Liberalization and Currency Substitution in Turkey. Journal of Economic Studies, 30, 514-534.

Dekle, R., \& Pradhan, M. (1997). Financial Liberalization and Money Demand in ASEAN Countries: Implications for Monetary Policy. IMF Working Paper WP/97/36.

Drake, L., \& Fleissig, A. (2004). Admissible Monetary Aggregates and UK Inflation Targeting. Money Macro and Finance (MMF) Research Group Conference 2004 No.2.

Goldfeld, M. (1973). The Demand for Money: Revisited. Brookings Papers on Economic Activity, 3, 577-646.

Haider, S., Ganaie, A.A., \& Kamaiah, B. (2017). Asymmetric Exchange Rate Effect on Money Demand under Open Economy in Case of India. Economics Bulletin, 37(1), 168-179.

Kamaruddin, A.A., \& Khalid, N. (2016). Symmetric and Asymmetric Approaches in Estimating the Money Demand Function for Malaysia: A Comparison between Simple Sum and Divisia Indexes. Jurnal Ekonomi Malaysia, 50(2), 181-195.

Katrakilidis, C., \& Trachanas, E. (2012). What Drives Housing Price Dynamics in Greech: New Evidence from Asymmetric ARDL Cointegration. Economic Modelling, 29, 1064-1069.

Khatat M.E.H. (2018). Monetary Policy and Models of Currency Demand. International Monetary Fund Working Paper $\mathrm{WP} / 18 / 28$

Leong, C.M., Puah, C.H., \& Ismail, S. (2018a). Divisia Monetary Model of Exchange Rate Determination: The Case of Philippines. Economic Annals-XXI, 172(7-8), 9-13.

Leong, C.M., Puah, C.H., \& Liew, V.K.S. (2018b). The Impact of Divisia Money on Monetary Model of Exchange Rate in Indonesia. Economics \& Sociology, 11(2), 52-63.

Leong, C.M., Puah, C.H., Shazali A.M., \& Lau, E. (2010). Testing the Effectiveness of Monetary Policy in Malaysia Using Alternative Monetary Aggregation. Margin: The Journal of Applied Economic Research, 4(3), 265-278.

Marashdeh, O. (1998). The Demand for Money in An Open Economy: The Case of Malaysia. International Finance 9801001, University Library of Munich.

McNown, R., \& Wallae, M.S. (1992). Cointegration Tests of a Long-run Relationship between Money Demand and the Effective Exchange Rate. Journal of International Money and Finance, 11, 107-114.

Ministry of Finance Malaysia (2018). Economic Outlook 2019. Ministry of Finance Malaysia, Putrajaya.

Mundell, A.R. (1963). Capital Mobility and Stabilization Policy under Fixed and Flexible Exchange Rates. Canadian Journal of Economics and Political Science, 20, 475-485.

Pesaran, M.H. \& Shin, Y. (1999). An Autoregressive Distributed Lag Modeling Approach to Cointegration Analysis. In S. Storm (Ed). Econometrics and Economic Theory in the 20th Century: The Ragnar Frish Centennial Symposium. Cambridge University Press: Cambridge.

Pesaran, M.H., Shin, Y. \& Smith, R.J. (2001). Bounds Testing Approaches to the Analysis of Level Relationships. Journal of Applied Econometrics, 16(3), 289-326.

Shin, Y., \& Yu, B., Greenwood-Nimmo, M. (2011). Modelling Asymmetric Cointegration and Dynamic Multiplier in a Nonlinear ARDL Framework, Mimeo.

Thornton, D.L., \& Yue, P. (1992). An Extended Series of Divisia Monetary Aggregates. Federal Reserve Bank of St. Louis Review, November/December, 35-52. 
Tsuzuki, E. (2016). Fiscal Policy Lag and Equilibrium Determinacy in a Continuous-time New Keynesian model. International Review of Econonomics, 63(3), 215-232.

Wlodarczyk, J. (2014). Nonneutrality of Money in a Social Perspective. Economics \& Sociology, 7(2), 199-208.

Wong H.T., \& Lee, H.A. (2016). Exchange Rate Volatility and Exports of Malaysian Manufactured Goods to China: An Empirical Analysis. International Journal of Business and Society, 17(1), 145-159. 